\title{
BIOLOGICAL ASPECTS OF THE EUROPEAN SEA BASS (DICENTRARCHUS LABRAX L., 1758) FROM BARDAWIL LAGOON, NORTH SINAI, EGYPT
}

\author{
Kariman A. Sh. Shalloof ${ }^{1 *}$; Attia A. O. El-Aiatt ${ }^{1}$; Saber M. Mohammed ${ }^{2}$ \\ ${ }^{1}$ Fisheries Biology Laboratory, ${ }^{2}$ Economic and Fish Statistics Laboratory, Fisheries Division, \\ National Institute for Oceanography and Fisheries (NIOF), Egypt
}

\section{Article History: \\ Received: 19 June 2019 \\ Revised: 23 July 2019 \\ Accepted: 26 July 2019 \\ Published Online: \\ 2 August 2019}

Keywords:

Bardawil Lagoon

Condition factor

Dicentrarchus labrax

Growth parameters

Length-weight relationship

*Correspondence:

Kariman Shalloof

Fisheries Biology Laboratory,

Fisheries Division, NIOF,

Egypt

E-mail:

dr_kariman88@yahoo.com

\begin{abstract}
The present study investigated the biological aspects of the European sea bass (Dicentrarchus labrax) from Bardawil Lagoon, North Sinai, Egypt. Monthly random samples of D. labrax were collected from the commercial catch of different landing sites of lagoon during two fishing seasons from May 2015 to December 2016. The length-weight relationship, condition factor, age composition, and fish growth were studied in the current study. The exponent " $b$ " of the length-weight relationship resulted in isometric mode of growth, since the value of $b=3.0067$ in the power equation: Weight $=0.0093$ $\times$ length $^{3.0067}$. The mean highest values of condition factor $(\mathrm{K})$ of D. labrax were recorded in November (where $\mathrm{K}=1.26$ ). Growth parameters such as the asymptotic length $\left(\mathrm{L}_{\infty}\right)$; growth rate $(\mathrm{k})$; the hypothetical age at which fish would have zero length $\left(\mathrm{t}_{0}\right)$, and the asymptotic body weight $(\mathrm{W} \infty)$ were estimated as $75.31 \mathrm{~cm}, 0.1221$ year $^{-1},-1.8703$ year and $4088.99 \mathrm{~g}$, respectively. Total mortality (Z), natural mortality (M), and fishing mortality $(\mathrm{F})$ were $0.8786,0.3153$, and 0.5633 year $^{-1}$, respectively. Exploitation rate (E) was 0.64, which indicated that the stock of the sea bass in the research area is heavily exploited. However, degree of well-being of D. labrax in the lagoon was detected. Overall, the present study concluded that it is essential to maximize the length at the first capture to be larger than that at the first sexual maturity $(>30.0 \mathrm{~cm}$ ) by widening the mesh size used to catch $D$. labrax to protect this species from extra-exploitation.
\end{abstract}

\section{INTRODUCTION}

Bardawil Lagoon (North Sinai, Egypt) plays an essential role in the fish production in Egypt, where it produces very economically important species of fishes such as sea bass, sea bream, common sole, grey mullet, eel, meager and white grouper ${ }^{[1]}$. Sea bass
(Dicentrarchus labrax L., 1758), belongs to family Moronidae. It is a demersal species found throughout the Mediterranean Sea and Eastern North Atlantic from Southern Morocco to the Norwegian littoral ${ }^{[2]}$. They are one of the important marine fishes in Bardawil Lagoon and have a great economic 
importance in Egypt. It reaches high prices in the market and is much appreciated nationally as the European sea bass is exported to Europe $^{[1]}$. It is the main demersal target of hand lines, long lines and trolling fisheries operating. The goal of growth studies of fish is to control the amount of fish that can be produced with contact of time. The annual change in a fishery affects its growth pattern ${ }^{[3]}$. The previous studies on D. labrax in the lagoon indicated that the exploited and fishing effort were above optimum levels ${ }^{[4]}$. According to the General Authority for Fish Resources Development (GAFRD) ${ }^{[5]}$ the production of sea bass in Lake Bardawil ranged from 26 to 90 tons in the period between 2003 and 2015, and then increased to about 124-134 tons during the fishing season of 2016-2017, which may affect the biological aspects of D. labrax. Therefore, the aim of the present study was to supplement information about the biological aspects of D. labrax in Bardawil Lagoon during years 2015 and 2016 that could be useful for management of this important species, and considered an important diagnostic system for the management of local fishery wealth, as well as of effective policies for future regional development.

\section{MATERIAL AND METHODS Area of study}

Lake Bardawil (a shallow, hyper-saline lagoon) lies in the north of Sinai, southern east the Mediterranean Sea. It located between $31^{\circ} 03^{\prime} \mathrm{N}$ to $31^{\circ} 14^{\prime} \mathrm{N}$ and between $32^{\circ} 40^{\prime} \mathrm{E}$ to $33^{\circ} 30^{\prime} \mathrm{E}$. The lagoon is shallow with a maximum depth of $6.5 \mathrm{~m}$ in its western arm, a minimum depth of $0.3 \mathrm{~m}$, and an average depth of $1.21 \mathrm{~m}^{[6]}$.

\section{Samples collection}

Monthly random samples of sea bass, D. labrax (Figure 1) were collected from the commercial catch in different landing sites of Bardawil Lagoon during two fishing seasons extends from May 2015 to December 2016 except February, March and April 2016, because fishing in Bardawil Lagoon is prohibited between January and April, in order to allow fish stocks to recuperate. In the laboratory, total fish length and total weight for 1865 specimens were measured to the nearest $0.1 \mathrm{~cm}$ and $0.1 \mathrm{~g}$, respectively. Fish specimens were dissected to determine its sex and maturity stages. Otoliths (oval shape with opaque edge) were obtained (Figure 2) and preserved for age determination by Optka trinocular stereomicroscope (Mode: SZM-2; Poteranica, Italy).

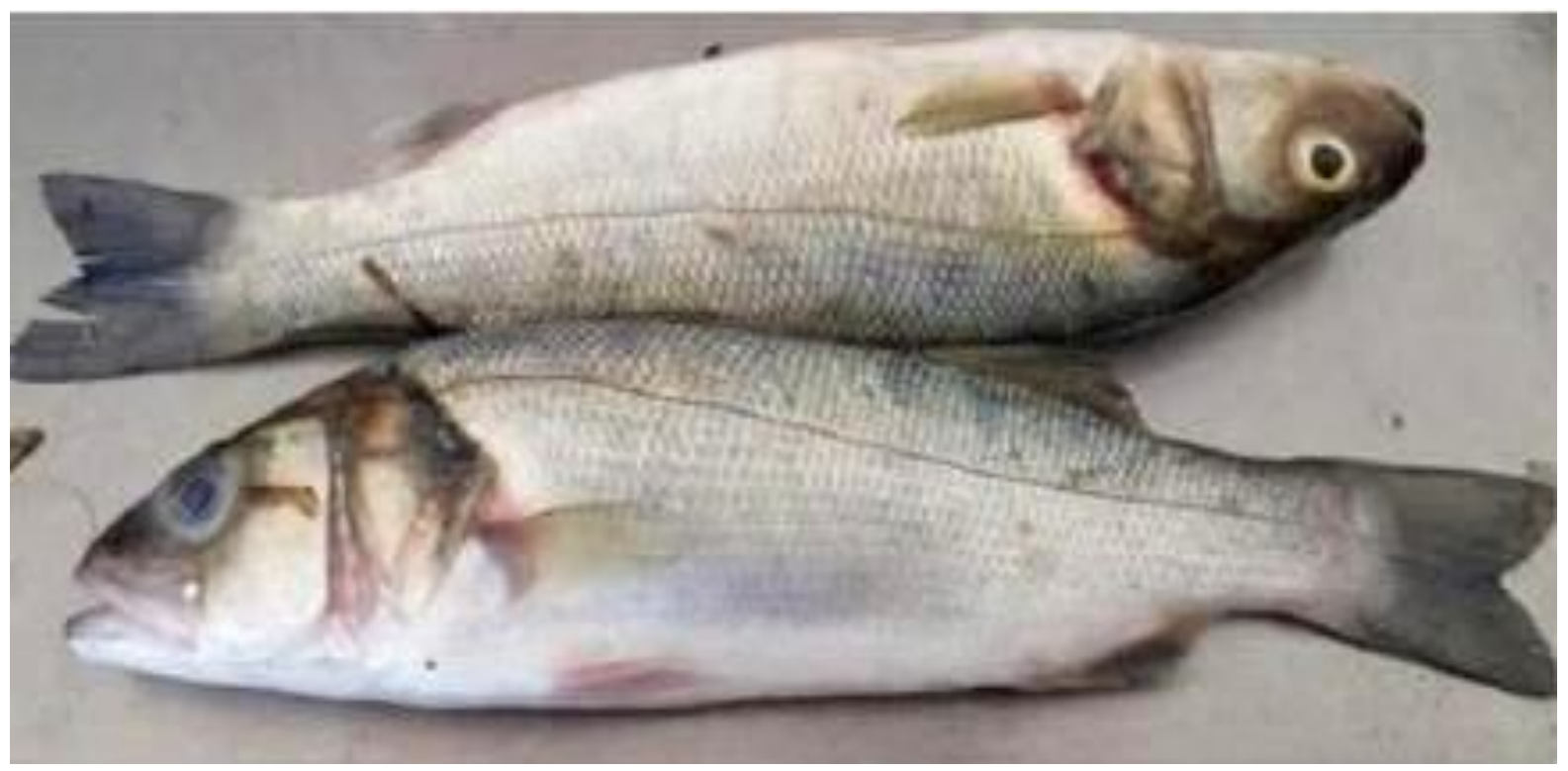

Figure 1: Sea bass, Dicentrarchus labrax, from Bardawil Lagoon. 
(a)

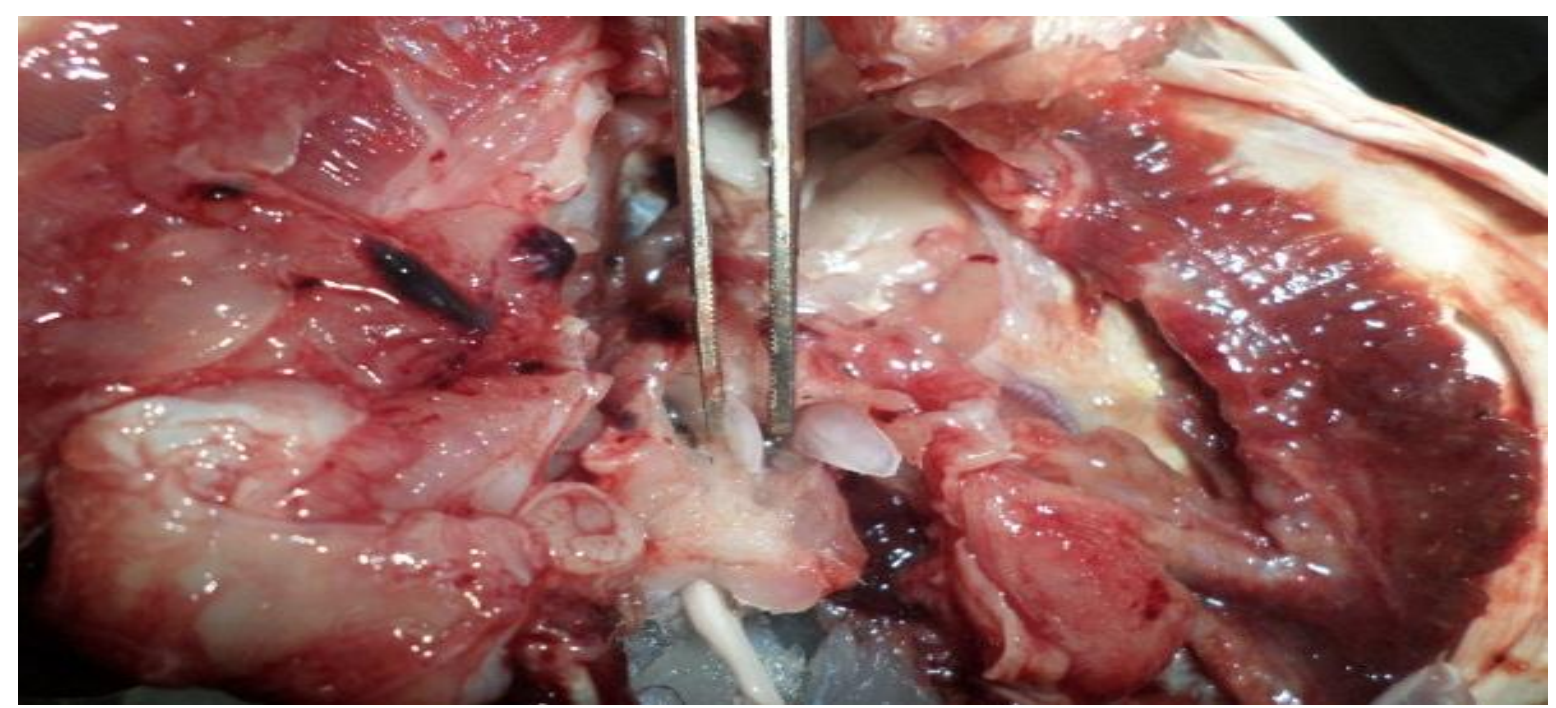

(b)

(c)
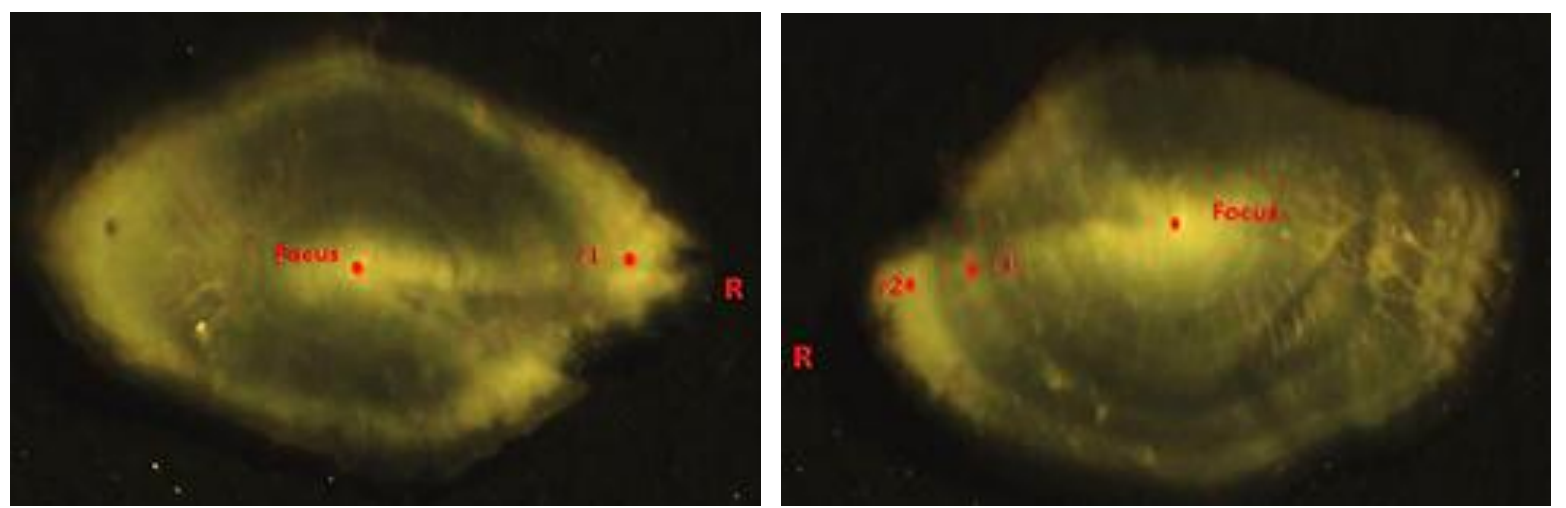

Figure 2: Otolith of sea bass, Dicentrarchus labrax, from Bardawil Lagoon (a) showed otolith extracting, (b and c) showed otolith of age groups 1 and 2, respectively, under the light microscope.

\section{Data analysis}

The relationship between length and weight was described by the following equation ${ }^{[7]}$ : $\mathrm{W}=\mathrm{aL}^{\mathrm{b}}$, where " $\mathrm{W}$ " is the total weight $(\mathrm{g})$, "L" is the total length (cm),"a and b" are constants. The condition factor $(\mathrm{K})$ was calculated monthly by the following formula ${ }^{[8]}: \mathrm{K}=\left(\mathrm{W} / \mathrm{L}^{3}\right) \times 100$. The otolith's measurements from 535 specimens were used to describe the relationship between the total length and the otolith radius. Three well-trained readers read growth increments to avoid any errors regarding the stucking zone. The disturbance rings and opaque rings including those located on the edge of the otolith were not counted in the current study; only the hyaline complete rings were counted. Fishing in Bardawil lagoon is prohibited between January and April by the competent authorities in order to allow fish stocks to recuperate, thus it was not possible to determine the season that rings were formed in the current study. Lengths by age were back-calculated using the following equation as cited by Ameran et al. ${ }^{[4]}: \mathrm{L}_{\mathrm{n}}=$ ( $L-$ a) $S_{n} / S+a$, where " $L_{n}$ " is the length of fish at age "n"; " $\mathrm{S}_{\mathrm{n}}$ " is a magnified otolith radius to " $n$ " annulus; " $\mathrm{S}$ " is a magnified total otolith radius; " $L$ " is a fish length at capture, "a" is constant derived from the relationship between total otolith radius and fish length at capture. The calculated weight 
at the end of each year was estimated by applying length-weight equation.

The parameters of the von Bertalanffy growth equation " $\mathrm{L}_{\mathrm{t}}=\mathrm{L}_{\infty}\left[1-\mathrm{e}^{-\mathrm{k}\left(\mathrm{t}-\mathrm{t}_{0}\right)}\right]$ " was used to describe growth in size as described previously ${ }^{[9]}$, where " $\mathrm{L}_{\mathrm{t}}$ " is the length at age " $t$ ", " $\mathrm{L}_{\infty}$ " is the asymptotic length, " $\mathrm{K}$ " is the body's growth coefficient, " $\mathrm{t}_{0}$ " is the hypothetical age at which fish would have zero length. $\mathrm{L}_{\infty}$ and $\mathrm{K}$ were computed according to Gulland ${ }^{[10]}$ and Ricker $^{[7]}$ by using the Ford-Walford plot. The growth performance index $(\varnothing)$ in length and weight also computed by the following two equations ${ }^{[11]}: \varnothing=\log K+2 \log L_{\infty}$ and $\varnothing=\log K+2 / 3 \log \mathrm{W}_{\infty}$, respectively. The maximum length with highest biomass $\left(\mathrm{L}_{\text {opt }}\right)$ computed by the following equation ${ }^{[12]}$ $\mathrm{L}_{\mathrm{opt}}=\mathrm{L}_{\infty} \times[3 /(3+(\mathrm{M} / \mathrm{K})]$.

Total mortality $(\mathrm{Z})$ was obtained by using the method of Powell-Wetherall plot ${ }^{[13,14]}$, where $Z=1-K$. The coefficient of natural mortality (M) was estimated by using the following equation ${ }^{[15]}$ : $\log \mathrm{M}=[-0.0066-$ $0.279 \log \mathrm{L}_{\infty}+0.6543 \log \mathrm{K}+0.4634$ $\log \mathrm{T}]$, where " $\mathrm{T}$ " is the annual average water temperature. Maximum age of the fish $\left(t_{\max }\right)=3 / K$, while fishing mortality $(F)$ $=\mathrm{Z}-\mathrm{M}$. The exploitation rate $(\mathrm{E})$ was calculated as follows: $\mathrm{E}=\mathrm{F} / \mathrm{Z}$. Length at first capture $\left(\mathrm{L}_{\mathrm{c}}\right)$ was calculated from the plot of the probability of capture against size. The method of Gulland ${ }^{[10]}$ was used to predict the yield per recruit as follows: $\mathrm{Y} / \mathrm{R}=\mathrm{F} \times \mathrm{e}^{-\mathrm{M}(\mathrm{Tc}-\mathrm{Tr})} \times \mathrm{W} \infty \times[(1 / \mathrm{Z})-$ $\left.(3 \mathrm{~S} / \mathrm{Z}+\mathrm{K})+\left(3 \mathrm{~S}^{2} / \mathrm{Z}+2 \mathrm{~K}\right)-\left(\mathrm{S}^{3} / \mathrm{Z}+3 \mathrm{~K}\right)\right]$, where $S=\mathrm{e}^{-\mathrm{k}(\mathrm{Tc}-\mathrm{t})}$, “Tc" is age at first capture, "Tr" is age at recruitment.

\section{RESULTS AND DISCUSSION}

GAFRD $^{[5]}$ mentioned that the total production of sea bass in Bardawil Lagoon increased to about 124 tons during the fishing season of 2016, as compared with 26-90 tons during 2003-2015 fishing seasons. This may be connected with the stopping the use of trawl nets in the lake (shrimp cloak), which destroyed large quantities of gilthead sea bream and sea bass.
The engines that occupy trawl nets are completely nuisance in the lake, which leads to the escape of fish to areas far from the fishing areas. This also may have occurred due to the great inconvenience caused by trawl nets engines that prevents the entry of fish from the Boughaz. Therefore, the fish entered to the lake during stop of fishing in the lake on Wednesday and Thursday. The evidence for this explanation is an increase in the amount of catch of D. labrax at the beginning of the week on Saturday.

The total length of 1865 specimens of sea bass, D. labrax, which caught from Bardawil Lagoon during period from May 2015 to December 2016 (except February, March and April 2016), were ranged from 18.4 to $65.3 \mathrm{~cm}$. It should be noted that wide length interval was observed, and the length interval "nearly from 40 to $65 \mathrm{~cm}$ " was the lowest percent (Figure 3). The length-weight relationship of all specimens was illustrated in Figure "4". It would appear that this relation indicates an isometric growth as the value of $b=3.0067$ in the power equation: $\mathrm{W}=0.0093 \times \mathrm{L}^{3.0067}$.

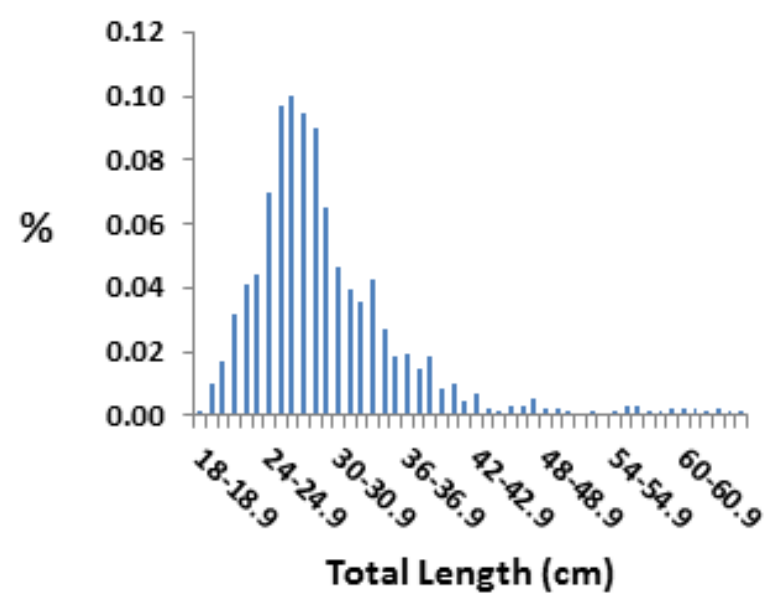

Figure 3: Length frequency distribution of D. labrax in Bardawil Lagoon, 2015-2016.

Olurin and Aderibigbe ${ }^{[16]}$ mentioned that fish displaying isometric growth when the length-upswing is in equal proportions with body weight for fixed specific gravity. The regression co-efficient for isometric growth 
is " 3 ", values greater or lesser than " 3 " referred allometric growth. Ahmed ${ }^{[17]}$ found that the relationship between length and weight of D. labrax in Bardawil Lagoon was estimated as $\mathrm{W}=0.014 \mathrm{~L}^{2.883}$. Gonçalves et $a l .{ }^{[18]}$ found that the length-weight relationship of D. labrax in the south and south-west coast of Portugal was $\mathrm{W}=$ $0.0060 \mathrm{~L}^{3.039}$. In addition, the length-weight relationship of D. labrax in Iskenderun Bay on the northeast end of the Levantine Sea (eastern Mediterranean Sea) was found to be $\mathrm{W}=0.0142 \mathrm{~L}^{2.9615}$ as cited by Erguden and Turan $^{[19]}$. Difference in $b$ values can be due to the combination of various factors such as number of specimens studied, habitat, and status of stomach fullness, gonadal maturity, sex, well-being, and overall fish condition, and the differences in the observed length ranges of the specimens caught ${ }^{[20]}$.

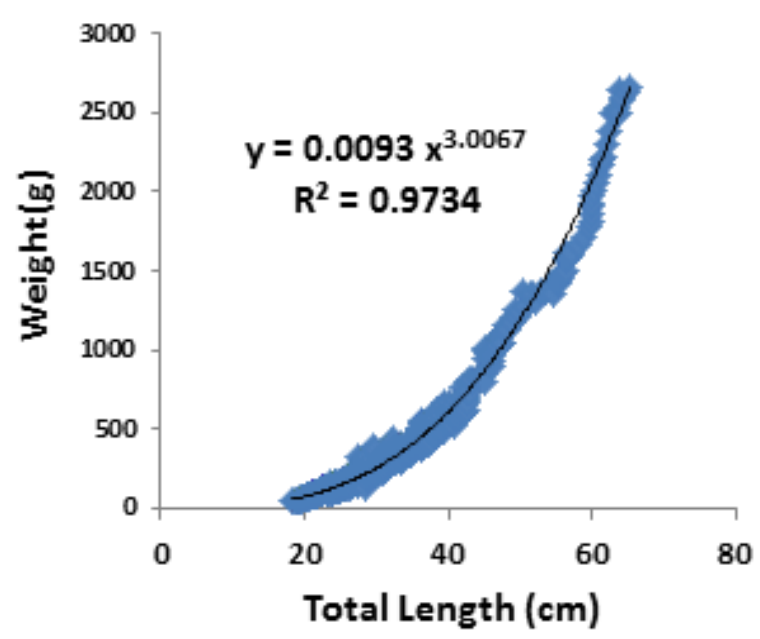

Figure 4: Length-weight relationship of D. labrax in Bardawil Lagoon, 2015-2016.

It has been found that the lowest mean values of condition factor $(\mathrm{K})$ of combined sexes (female and male) of D. labrax were recorded in June (1.00), while the highest values were recorded in November (1.26). Our results demonstrated that $\mathrm{K}$ value of females was better in October and November than the other months, since it composed 1.37 and 1.48 , respectively (Figure 5). These findings support the notion that the spawning period of the studied species occur in this period. The $\mathrm{K}$ value of sea bass D. labrax in Bardawil Lagoon varied from 1.82 and 1.94 with a mean of 1.01 as mentioned by Abdel-Hakim et al. ${ }^{[1]}$. Condition factor recorded for sea bass captured from El-Maadiya region $=1.044$, as recorded by Bakhoum et al. ${ }^{[21]}$.

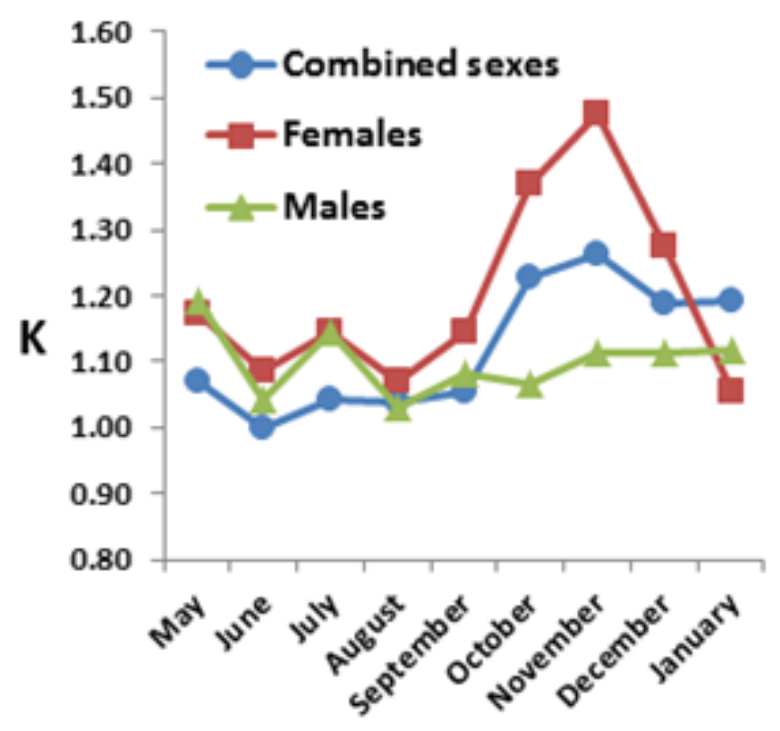

Figure 5: Monthly variation in condition factor $(\mathrm{K})$ of male, female and combined sexes of D. labrax in Bardawil Lagoon, 2015-2016.

Age distribution of 535 D. labrax samples from Bardawil Lagoon ranged from 0 to 6 years based on results of the otoliths reading (Figure 6). The age group 1 was a dominant group and composed $30.7 \%$ of the whole age distribution. The group 1 was followed by the age group $2(19.6 \%)$, group $0(17.9 \%)$, group $3(16.4 \%)$. The age groups 4,5 and 6 were representing with low percentage in the population (Figure 6). This result is in good agreement with the findings of Ahmed ${ }^{[17]}$ and Erguden and Turan $^{[19]}$, where the age composition of sea bass D. labrax lives in Bardawil Lagoon and Iskenderun Bay varied between 0-6 age groups too. In the present study, the low percentages of the age groups 4,5 , and 6 in the population means that there is a catching pressure (fishing effort) on this species, as recorded by Erguden and Turan ${ }^{[19]}$. They 
also reported that excessive fishing can cause many morphological changes in growth rate $(\mathrm{k})$, body length and weight, sexual maturation time, sexual maturation age, fecundity and spawning time for this species. Catching pressure of this species in the area of study was indicated also by wide length interval, and the length interval nearly from 40 to $65 \mathrm{~cm}$ constituting the lowest percent. Minimum, maximum and mean lengths of different age groups of D. labrax in Bardawil lagoon (Table 1) showed overlapping in lengths between all recorded age groups.

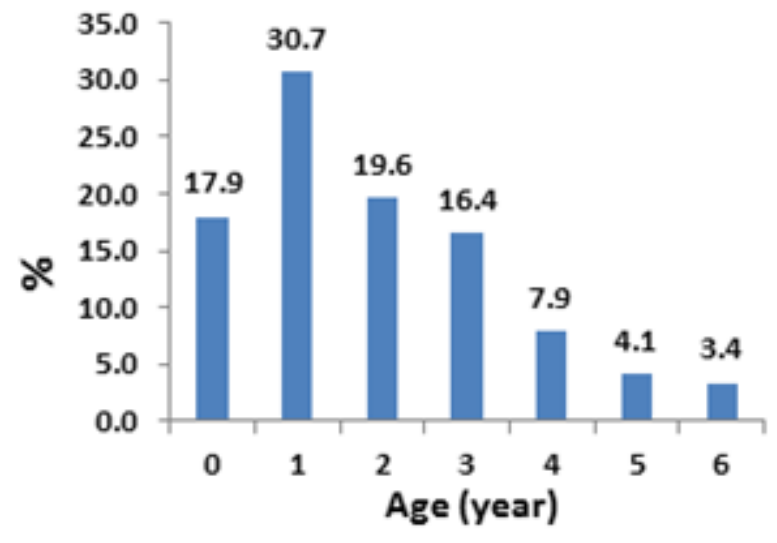

Figure 6: Age distribution of D. labrax in Bardawil Lagoon, 2015-2016.

Table 1: Minimum, maximum and mean lengths of different age groups of D. labrax in Bardawil lagoon, 2015-2016.

\begin{tabular}{cccccc}
\hline Age & $\begin{array}{c}\text { Samples } \\
\text { Number }\end{array}$ & $\begin{array}{c}\text { Minimum } \\
\text { Length }(\mathrm{cm})\end{array}$ & $\begin{array}{c}\text { Maximum } \\
\text { Length }(\mathrm{cm})\end{array}$ & $\begin{array}{c}\text { Mean } \\
\text { Length }(\mathrm{cm})\end{array}$ & $\begin{array}{c}\text { Standard } \\
\text { Error }\end{array}$ \\
\hline 0 & 96 & 18.8 & 22.3 & 20.93 & 0.0871 \\
1 & 164 & 22.0 & 27.0 & 24.16 & 0.1048 \\
2 & 105 & 25.1 & 33.5 & 29.76 & 0.2140 \\
3 & 88 & 30.8 & 40.1 & 35.20 & 0.1919 \\
4 & 42 & 37.9 & 47 & 40.70 & 0.3672 \\
5 & 22 & 42.5 & 48.3 & 45.59 & 0.4096 \\
6 & 18 & 46.3 & 65 & 55.16 & 1.6223 \\
Total Samples & 535 & & & & \\
\hline
\end{tabular}

The back-calculated lengths recorded in this study were $22.3,28.3,34.0,38.4$, 42.6 and $46.5 \mathrm{~cm}$ for age groups $1,2,3,4,5$ and 6 years, respectively (Figure 7). The results showed that the highest increment in length occurred at the first year of life $(22.3 \mathrm{~cm})$ and then declined rapidly thereafter till reached $3.9 \mathrm{~cm}$ at age of group 6. The increments in weight were $104.7,111.5,157.9,163.6,199.9$ and $221.9 \mathrm{~g}$ for age groups $1,2,3,4,5$ and 6 years respectively (Figure 8). The backcalculated weight was 104.7, 216.2, 374.0, 537.7, 737.6 and $959.5 \mathrm{~g}$ for age groups 1 , $2,3,4,5$ and 6 years, respectively. Growth parameters $\mathrm{L}_{\infty}, \mathrm{K}, \mathrm{t}_{0}$ and $\mathrm{W}_{\infty}$ were estimated as $75.31 \mathrm{~cm}, 0.1221$ year $^{-1},-1.8703$ year, and $4088.99 \mathrm{~g}$, respectively. The equations obtained were as follows: $\mathrm{L}_{\mathrm{t}}=75.31[1-$ $\left.\mathrm{e}^{-0.1221(\mathrm{t}+1.8703)}\right]$ for length, and $\mathrm{W}_{\mathrm{t}}=$ $4088.99\left[1-e^{-0.1221}(t+1.8703)\right]^{3.0067}$ for weight. The growth performance index ( $\Phi$ and $\Phi^{\prime}$ ) defined as 2.84 and 1.4943 for length and weight, respectively. Maximum length with the highest biomass $\left(\mathrm{L}_{\text {opt }}\right)$ was $40.5 \mathrm{~cm}$ and maximum age $\left(\mathrm{T}_{\text {max }}\right)$ was 24.6 years.

In the present study, Z, M, and F values were $0.8786,0.3153$ and 0.5633 year $^{-1}$, respectively. E value was recorded as 0.64 year $^{-1}$. According to Ricker ${ }^{[7]}$, the $M$ value represents deaths from all occasion, except man's fishing involving predation, senility, epidemics, pollution, etc. 


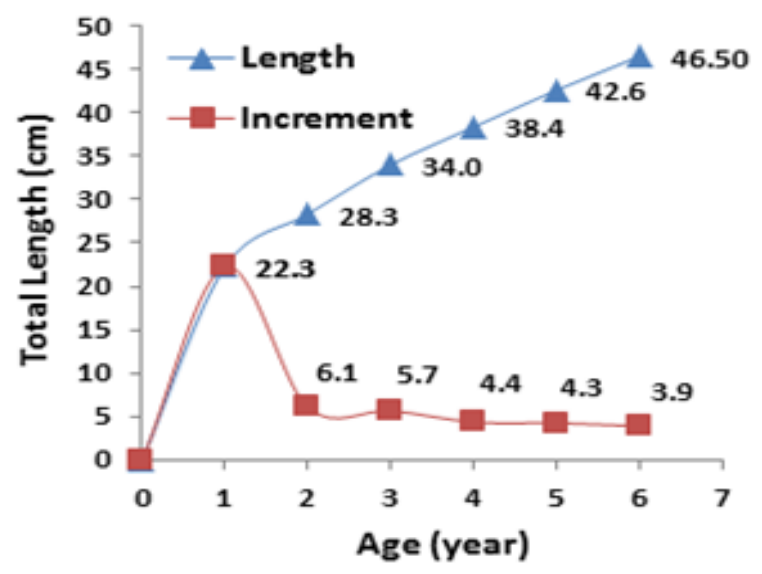

Figure 7: Increment in length of D. labrax in Bardawil Lagoon, 2015-2016.

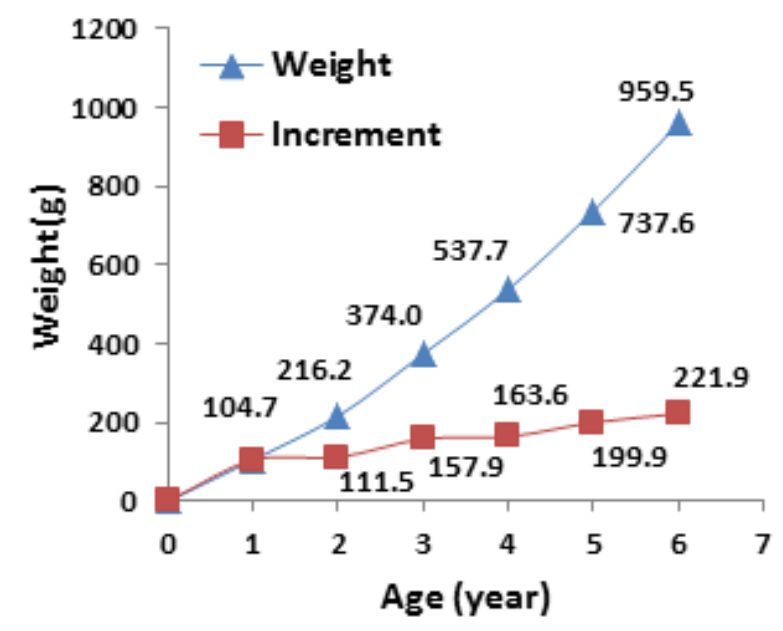

Figure 8: Increment in weight of D. labrax in Bardawil Lagoon, 2015-2016.

Bakhoum et al. ${ }^{[21]}$ recorded that, the mean value of $M$ coefficient for sea bass captured from El-Maadiya region (Egyptian Mediterranean Sea water) was 0.172. Growth parameters such as $\mathrm{L}_{\infty}, \mathrm{k}$ and $\mathrm{t}_{\mathrm{o}}$ were calculated as $70.82 \mathrm{~cm}, 0.35$ year $^{-1}$, and -0.217 year $^{-1}$, respectively, as mentioned by Ahmed $^{[17]}$. He also found that $\mathrm{Z}, \mathrm{M}$, and $\mathrm{F}$ values were 1.03 year $^{-1}, 0.39$ year $^{-1}$ and 0.64 year $^{-1}$, respectively, and $\mathrm{E}$ value $=$ 0.6229 indicated that the stock of sea bass in Bardawil Lagoon is heavily exploited. The von Bertalanffy growth Parameters of D. labrax in Welsh waters (both sexes) were estimated $\left(\mathrm{L}_{\infty}=78.99, \mathrm{~K}=0.103\right.$ and $\left.\mathrm{t}_{0}=-0.890\right)^{[22]}$. In the present study, the rate of $\mathrm{F}(0.5633)$ and $\mathrm{E}$ (0.64) reflect high values, so we attain maximum yield per recruit $(Y / R)$ at $F=0.6$. Because we have already high effort, Bardawil Lagoon must be better managed by widening the mesh size of the net to avoid catching small fish, especially fish that is captured by trammel net (El-Dabba).

Table "2" illustrates comparison of biological items of D. labrax in Bardawil Lagoon during different fishing seasons. This table gives an indication of the degree of welfare of D. labrax in the lagoon during the present study, since $b=3.0067$ (i.e. higher than that recorded in the previous fishing seasons in the lagoon). Also, Table "2" demonstrated that the recorded value of $M$ in the present study was less than that in the previous fishing seasons in the lagoon. This may be due to ban of trawling net (El-Kalssa) by the Egyptian authorities. The yield per recruit (Y/R) was found to be $156.93 \mathrm{~g}$ and $156.97 \mathrm{~g}$ at the actual $\mathrm{F}=$ 0.5633 and 0.6 year $^{-1}$, respectively. Biomass per recruit was decreased with the increasing of $\mathrm{F}$ value, where its maximum value (982.3 g) at $\mathrm{F}=0.0$ (Figure 9).

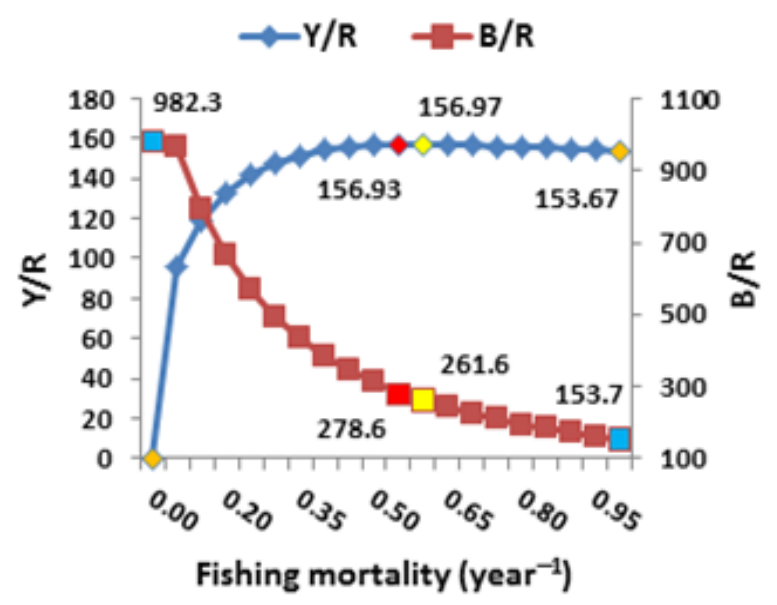

Figure 9: Yield per recruit (Y/R) and biomass-per-recruit $(\mathrm{B} / \mathrm{R})$ of $D$. labrax in Bardwil Lagoon, 2015-2016.

The $\mathrm{L}_{\mathrm{c}}$ value in the present study was estimated as $27.8 \mathrm{~cm}$ (Figure 10) corresponding to an age of 1.904 year. $\mathrm{L}_{\mathrm{c}}$ was estimated as $26.8 \mathrm{~cm}$ as reported 
by Ameran et $a .^{[4]}$. The length at first mature $\left(\mathrm{L}_{50}\right)$ in the same studied fishing season (2015-2016) was determined as 30.8 and $29.2 \mathrm{~cm}$ for females and males, respectively ${ }^{[23]}$. So, it is essential to maximize $\mathrm{L}_{\mathrm{c}}$ larger than the length at first sexual maturity (> $30.0 \mathrm{~cm})$ by widening the mesh size used to catch D. labrax. Mehanna et al. ${ }^{[24]}$ found that the $\mathrm{L}_{\mathrm{c}}$ at which $50 \%$ of the fish are vulnerable to capture was $31.5 \mathrm{~cm}$, which corresponding to an age of 1.61 year. They also concluded that reducing the $E$ value and increasing the $L_{c}$ can be achieved through regulating the mesh and hook sizes, proposing the total allowable catch from the lagoon, and protecting the spawning stocks during their spawning migrations from/into the lagoon. Also, the destructive fishing gears such as kalsa and dahbana nets should be banned meanwhile; the technological development and biological effect of several fishing methods operating inside the lagoon should also be taken into account when analyzing the impact of the fishery on the different fish stocks.

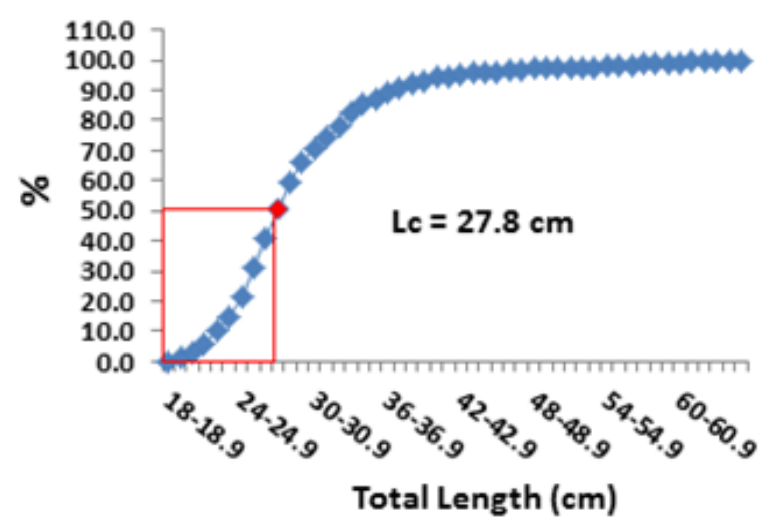

Figure 10: Length at first capture $\left(\mathrm{L}_{\mathrm{c}}\right)$ of D. labrax in Bardwil Lagoon, 2015-2016.

Table 2: Comparison of the biological aspects of D. labrax in Bardawil Lagoon during different fishing seasons.

\begin{tabular}{cccccc} 
& & \multicolumn{4}{c}{ References } \\
Fishing season & {$[4]$} & {$[1]$} & {$[24]$} & {$[17]$} & The current study \\
\cline { 2 - 6 } a & 2004 & 2008 & 2008 & $2009 / 2010$ & $2015-2016$ \\
b & 0.0175 & 0.0187 & 0.0138 & 0.014 & 0.0093 \\
$\mathrm{~L}_{\mathrm{c}}(\mathrm{cm})$ & 2.8261 & 2.824 & 2.8913 & 2.883 & 3.0067 \\
$\mathrm{~L}_{\infty}(\mathrm{cm})$ & 26.8 & - & - & - & 27.8 \\
$\mathrm{k}\left(\right.$ year $\left.^{-1}\right)$ & 52.23 & - & 76.36 & 70.82 & 75.31 \\
$\mathrm{t}_{0}\left(\right.$ year $^{-1}$ & 0.2165 & - & 0.29 & 0.35 & 0.1221 \\
$\mathrm{Z}\left(\right.$ year $\left.^{-1}\right)$ & -1.4643 & - & -0.19 & -0.217 & -1.8703 \\
$\mathrm{M}\left(\right.$ year $\left.^{-1}\right)$ & 2.41 & - & 1.54 & 1.03 & 0.8786 \\
$\mathrm{~F}\left(\right.$ year $\left.^{-1}\right)$ & 0.48 & - & 0.36 & 0.39 & 0.3153 \\
E & 1.93 & - & 1.18 & 0.64 & 0.5633 \\
& 0.8 & - & 0.766 & 0.623 & 0.64 \\
\hline
\end{tabular}

$a$ and $b$ : length-weight relationship parameters, $\mathrm{L}_{c}$ : length at first capture, $\mathrm{L}_{\infty}$ : asymptotic length, $\mathrm{k}$ : growth rate, $\mathrm{t}_{0}$ : the hypothetical age at which fish would have zero length, $\mathrm{Z}$ : total mortality, M: natural mortality, F: fishing mortality, E: exploitation rate.

\section{CONCLUSION}

Since the $b$ value of dependence of length upon weight exhibits isometric growth, a degree of well-being of D. labrax in the lagoon was detected. Also, 6 age groups were detected. The $\mathrm{M}$ value in the present study was less than that recorded in the previous fishing seasons in the lagoon. 
However, the stock of sea bass in Bardawil Lagoon is heavily exploited since E value was 0.64 year $^{-1}$. This study confirmed that fishing effort and exploitation rate of D. labrax was above the optimum level in Bardawil Lagoon. Therefore, the present study recommended that it is essential to maximize the length at the first capture larger than the length at the first sexual maturity $(>30.0 \mathrm{~cm})$ by widening the mesh size used to catch D. labrax to protect this species from exploitation.

\section{ACKNOWLEDGMENTS}

This research received no specific grant from any funding agency in the public, commercial or not-for-profit sectors. The authors report no declarations of interest.

\section{REFERENCES}

[1] Abdel-Hakim, N. F.; Mehanna, S. F.; Eisa, I. A. et al. (2010). Length weight relationship, condition factor and stomach contents of the European sea bass, Dicentrarchus labrax at Bardawil Lagoon, North Sinai, Egypt. Proceeding of the $3^{\text {rd }}$ Global Fisheries and Aquaculture Research Conference, Egypt, 1-14.

[2] Fritsch, M.; Morizur, Y.; Lambert, E. et al. (2006). Assessment of sea bass (Dicentrarchus labrax, L.) stock delimitation in the Bay of Biscay and the English Channel based on markrecapture and genetic data. Fish Res, 83(2-3): 123-132.

[3] Mayank, P.; Tyagi, R. K. and Dwivedi, A. C. (2015). Studies on age, growth and age composition of commercially important fish species, Cirrhinus mrigala (Hamilton, 1822) from the tributary of the Ganga river, India. Euro J Exp Bio, 5(2): 16-21.

[4] Ameran, M.; Salem, M.; El-Aiatt, A. et al. (2008). Age, growth and mortality of the sea bass, Dicentrarachus labrax from the Bardawil Lagoon, North Sinai, Egypt.
J Egypt Acad Soci Environ Develop, 9(2): 43-57.

[5] GAFRD (2018). The General Authority for Fishery Resources Development: Fisheries Statistics Year Book for 2016. Ministry of Agriculture and Land Reclamation, Cairo, Egypt.

[6] Zaghloul, F. A.; El Aiatt, A. A.; Hussien, N. R. et al. (2018). Recent variability in the plankton structure of a natural hypersaline lagoon; Bardawil Lagoon in northern Sinai, Egypt. Asian J Adv Basic Sci, 6(1): 58-68.

[7] Ricker, W. E. (1975). Computation and Interpretation of Biological Statistics of Fish Populations. Bulletin of the Fisheries Research Board of Canada, Bulletin 191, Information Canada, Ottawa.

[8] Azab, A. M.; El-Far, A. M. and El-Sayed, A. M. (2019). Age, growth and population structure of bogue, Boops boops, in the Mediterranean waters front Alexandria, Egypt. Egyptian Journal of Aquatic Biology and Fisheries, 23(3): 69-81.

[9] Liang, C. and Pauly, D. (2017). Growth and mortality of exploited fishes in China's coastal seas and their uses for yield-per-recruit analyses. J Appl Ichthyol, 33: 746-756.

[10] Gulland, J. A. (1969). Manual of Methods for Fish Stock Assessment. Part 1. Fish Population Analysis. FAO, Rome, Italy.

[11] Pauly, D. and Munro, J. L. (1984). Once more on the comparison of growth in fish and invertebrates. Fishbyte, 2(1): 21.

[12] Froese, R.; Stern-Pirlot, A.; Winker, H. et al. (2008). Size matters: how single-species management can contribute to ecosystem-based fisheries management. Fish Res, 92: 231-241.

[13] Powell, D. G. (1979). Estimation of mortality and growth parameters from the length frequency of a catch [model]. Rapports et Proces-Verbaux des Reunions (Denmark), 175: 167169. 
[14] Wetherall, J. A.; Polovina, J. J. and Ralston, S. (1987). Estimating growth and mortality in steady-state fish stocks from length-frequency data. In: Length-Based Methods in Fisheries Research (Pauly, D. and Morgan, G. R., eds.), pp. 53-74. ICLARM Conference Proceedings 13, International Center for Living Aquatic Resources Management, Manila, Philippines, and Kuwait Institute for Scientific Research, Safat, Kuwait.

[15] Pauly, D. (1980). On the interrelationships between natural mortality, growth parameters, and mean environmental temperature in 175 fish stocks. J Cons Int Explor Mer, 39(2): 175-192.

[16] Olurin, K. B. and Aderibigbe, O. A. (2006). Length-weight relationship and condition factor of pond reared juvenile Oreochromis niloticus. World J Zool, 1(2): 82-85.

[17] Ahmed, M. S. (2011). Population dynamic and fisheries management of Europen sea bass, Dicentrarchus labrax (F. Moronidae) from Bardawil Lagoon, North Sinai, Egypt. Egyptian Journal of Aquatic Biology and Fisheries, 15(1): 43-56.

[18] Gonçalves J. M. S.; Bentes L.; Lino, P. G. et al. (1997). Weight-length relationships for selected fish species of the small-scale demersal fisheries of the south and south-west coast of Portugal. Fish Res, 30: 253-256.

[19] Erguden, D. and Turan, C. (2005). Growth properties of sea bass (Dicentrarchus labrax (L., 1758),
Perciformes: Moronidae) live in Iskenderun Bay Pak J Biol Sci, 8(11): 1584-1587.

[20] Abowei, J. F. N.; Daviesand, O. A.; Eli, A. A. et al. (2009). Study of the length-weight relationship and condition factor of five fish species from Nkoro River, Niger Delta, Nigeria. Curr Res J Bio Sci, 1(3): 94-98.

[21] Bakhoum, S. A.; El-Bermawi, N. M.; Srour, T. M. et al. (2015). Some biological aspects of European seabass Dicentrarchus labrax in Egyptian Mediterranean water and aquaculture, Egypt. Mediterranean Aquaculture Journal, 7: 22-35.

[22] Cambiè, G.; Kaiser, M. J.; Hiddink, J. G. et al. (2015). Population Dynamics of the European Sea Bass (Dicentrarchus labrax) in Welsh Waters and Management Implications. Fisheries \& Conservation report No. 56, Bangor University, Bangor, UK.

[23] Shalloof, K. A. Sh. and El-Aiatt, A. A. O. (2019). Reproductive biology of European sea bass, Dicentrarchus labrax from Bardawil Lagoon, North Sinai, Egypt. Abbassa Int J Aqua, 12: 53-64.

[24] Mehanna, S. F.; El-Aiatt, A. A.; Ameran, M. A. et al. (2010). Population dynamics and fisheries regulations for the European sea bass Dicentrarchus labrax (Moronidae) at Bardawil Lagoon, Egypt. Proceeding of the $3^{\text {rd }}$ Global Fisheries and Aquaculture Research Conference, Egypt, 199-209.

\section{How to cite this article:}

Shalloof, K. A. Sh.; El-Aiatt, A. A. O. and Mohammed, S. M. (2019). Biological aspects of the European Sea bass (Dicentrarchus labrax L., 1758) from Bardawil Lagoon, North Sinai, Egypt. Egyptian Journal of Zoology, 72: 11-21 (DOI: 10.12816/ejz.2019.13399.1009). 


\title{
الجوانب البيولوجية لأسماك القاروص الأوروبية من بحيرة البردويل، شمال سيناء، مصر
}

\author{
كريمان أحمد شوقى شلوف1، عطية على عمر العياط1، صابر مصطفى محمد2

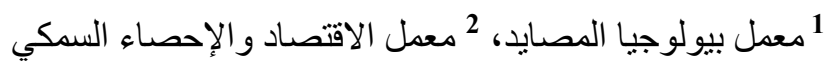

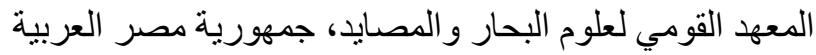

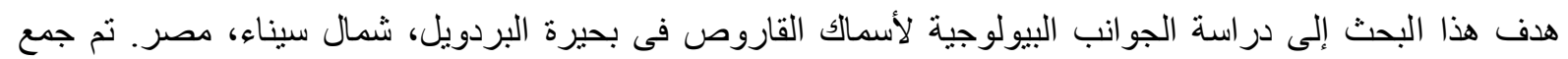

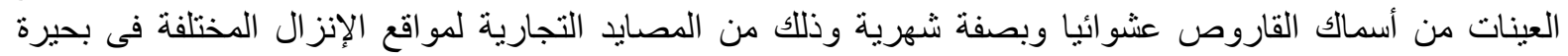

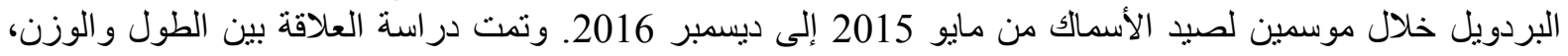

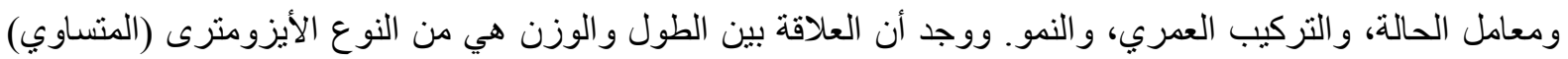

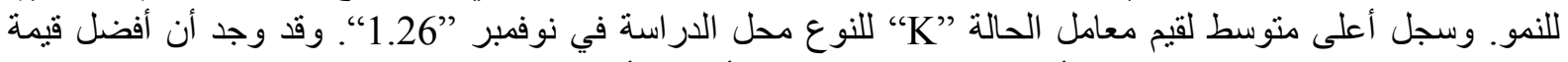

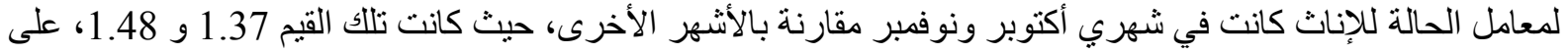

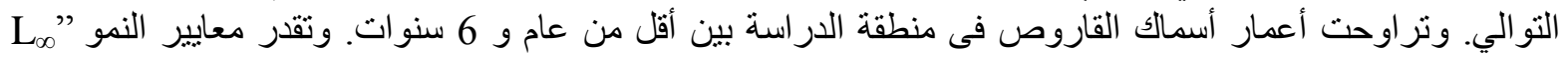

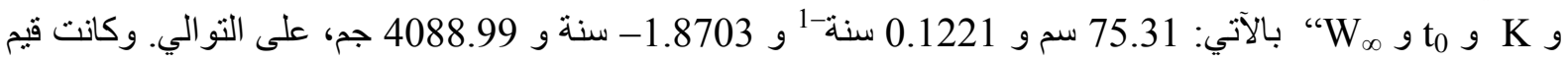

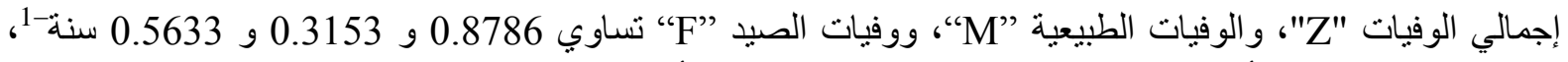

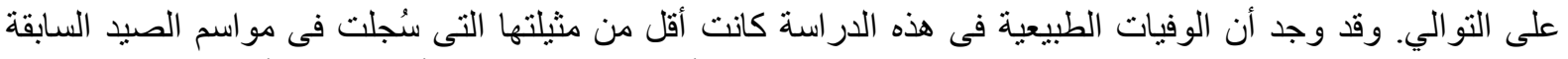

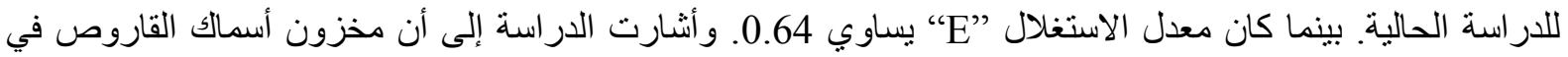

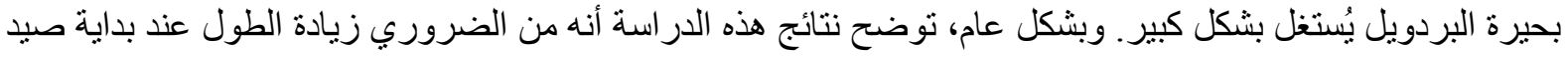

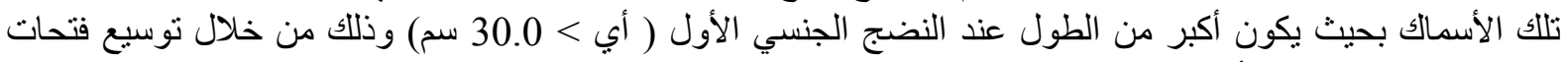

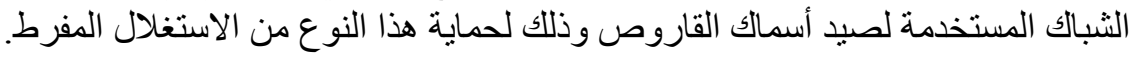

